\title{
Climate change, food security, and livelihoods in sub-Saharan Africa
}

\author{
Liette Connolly-Boutin · Barry Smit
}

Received: 16 December 2013/ Accepted: 26 January 2015/Published online: 13 February 2015

(c) The Author(s) 2015. This article is published with open access at Springerlink.com

\begin{abstract}
Sub-Saharan Africa is particularly vulnerable to climate change. Multiple biophysical, political, and socioeconomic stresses interact to increase the region's susceptibility and constrain its adaptive capacity. Climate change is commonly recognized as a major issue likely to have negative consequences on food security and livelihoods in the region. This paper reviews three bodies of scholarship that have evolved somewhat separately, yet are inherently interconnected: climate change impacts, vulnerability and adaptation, food security, and sustainable livelihoods. The paper develops a conceptualization of the relationships among the three themes and shows how food security's vulnerabilities are related to multiple stresses and adaptive capacities, reflecting access to assets. Food security represents one of several livelihood outcomes. The framework shows how several research paradigms relate to the issue of food security and climate change and provides a guide for empirical investigations. Recognizing these interconnections can help in the development of more effective policies and programs. The framework is applied here to synthesize findings from an array of studies in subSaharan Africa dealing with vulnerability to climate change, food security, and livelihoods.
\end{abstract}

Keywords Livelihoods - Climate change - Vulnerability · Adaptation · Sub-Saharan Africa · Food security

Editor: Marc J. Metzger.

L. Connolly-Boutin $(\bowtie) \cdot$ B. Smit

Department of Geography, University of Guelph, Guelph,

ON N1G 2W1, Canada

e-mail: 1connoll@uoguelph.ca

\section{Introduction}

Humanitarian crises associated with environmental conditions on the African continent, such as serious and sustained droughts, exemplify the vulnerability of people and communities in rural developing economies to acute physical stresses. These shocks act on communities whose vulnerability is affected in part by poverty and weak institutional support, and can have devastating consequences for people's food security and livelihoods. Food insecurity results from complex interactions of multiple stressors (socioeconomic and environmental) over long time periods and with sudden shocks (Swift 1989; Misselhorn 2005; Devereux 2007; Akrofi et al. 2012). Chronic drivers, which include poverty, environmental stressors, the absence of property rights, and poor market access, create a vulnerable environment where short-term drivers (e.g., food price increases) stress the communities (Misselhorn 2005). These interactions occur at different scales and can result in unexpected livelihood outcomes (O'Brien et al. 2009).

Climate change is an emerging stressor that is experienced over longer time frames via changes in climatic norms and over shorter periods via changes in the frequency and severity of extreme weather events. Climate change is commonly recognized to have major implications for food security and livelihoods (Thompson and Scoones 2009). In sub-Saharan Africa, extreme droughts already impede people's ability to grow food and rear livestock, and pastoralists and agro-pastoralists will need to adapt to changes in water regimes in order to maintain their food security and well-being (Kebede et al. 2011; Songok et al. 2011b).

The research on climate change impacts, vulnerability, and adaptation (sometimes called IVA) has provided several perspectives on the implications of climate change for 
food security and livelihoods. Somewhat different perspectives on this issue are provided by research in the field of food security/insecurity and by insights from the field of sustainable rural livelihoods. This paper explores the relationships among these three fields of research. While climate change is likely to affect food security and livelihoods throughout the world, this review focusses on subSaharan Africa, especially rural communities.

Sub-Saharan Africa is vulnerable to climate change, as multiple biophysical, political, and socioeconomic stresses interact to heighten the region's susceptibility and constrain its adaptive capacity (Davidson et al. 2003; Reid and Vogel 2006; IPCC 2007). Beyond increases in temperature, climate change in sub-Saharan Africa is expected to cause changes in rainfall intensity (Thomas et al. 2007; Songok et al. 2011a), increases in the incidence of extreme events such as droughts and floods (Richard et al. 2001; Fauchereau et al. 2003; New et al. 2006; Niang et al. 2014; Tschakert et al. 2010), increases in desertification (Reich et al. 2001), and alterations in certain disease vectors causing changes in the spatial and temporal transmission of infectious diseases (Hay et al. 2002; Chen et al. 2006). Expected impacts include shortened or disrupted growing seasons, reductions in the area suitable for agriculture, and declines in agricultural yields in many regions of subSaharan Africa (Niang et al. 2014; Müller et al. 2011; Sarr 2012).

It is estimated that the livelihoods of $70 \%$ of Africans are dependent on rain-fed agriculture, an activity that is characterized by small-scale, subsistence farms that are vulnerable to a variety of stresses, including those associated with climate change (Challinor et al. 2007; World Bank 2009). Due to its largely adverse effects on African agriculture and livelihoods, climate change is expected to have a negative impact on food security (Niang et al. 2014; Challinor et al. 2007; Brown et al. 2009; Thornton et al. 2011).

Most of the research on climate change impacts related to food in Africa, as evident in IPCC assessments, focuses on changes in crop yields and food production (Niang et al. 2014; Porter et al. 2014). The food security literature shows that food security is dependent not only on food production but also on food access and food utilization (Misselhorn 2005). While food security is a fundamental requirement for human sustenance, people's well-being is also influenced by other aspects of their livelihoods, such as income, health, and assets (Bashir and Schilizzi 2013). The literature on sustainable livelihoods demonstrates that livelihoods are composed of a combination of assets (or capitals) that allow people to follow a combination of strategies to attain livelihood outcomes (including better or worse food security) (Scoones 1998; Carney et al. 1999).
Improving our understanding of the relationships among climate, food, and livelihoods is more than a scholarly imperative-it is also necessary to help guide practical initiatives, such as policies, programs, and actions (including climate change adaptation), intended to sustain or improve the livelihoods and food security of people in sub-Saharan Africa as the climate continues to change. Initiatives that do not recognize the interrelationships run the risk of being ineffective. For example, Perch (2011) shows how climate change adaptation policies [such as the climate change National Adaptation Plans of Action (NAPAs)] that are crafted without considering the livelihoods of vulnerable groups are unlikely to succeed. Similarly, Levine et al. (2004) demonstrate how food security interventions that did not recognize livelihoods failed to meet the needs of the targeted communities.

The aim of this paper is to summarize and assess the knowledge from the three fields of research, to identify their synergies, and to provide an integrated conceptualization of how climate change affects the livelihoods and food security of people living in rural communities, particularly in sub-Saharan Africa. The paper begins with a review of the three fields: climate change IVA, food security, and sustainable livelihoods. On the basis of the interconnections among the three fields, and drawing on other integrated models, a conceptual framework is presented that brings together elements from the fields in order to provide a structure for understanding the implications of climate change on food security and livelihoods. The framework is then employed to structure a review of findings about climate change and food security in subSaharan Africa.

\section{Climate change impacts, vulnerability, and adaptation (IVA)}

Researchers addressing climate change IVA have studied issues related to food security using several approaches. One common research strategy is to predict the impacts of climate change on food production based on climate scenarios from global climate or general circulation models (GCMs). These studies start with projections of greenhouse gas emissions that are input into GCMs to estimate future climate norms, notably mean temperature. Estimates are derived for changes in agro-climatic norms, such as precipitation (Funk et al. 2008), the length of the growing season (Sarr 2012), water availability, and soil moisture (Kunstmann and Jung 2005). Using these scenarios and models of plant phenology or statistical estimates of yields, impacts on future crop yields are calculated. Then, with assumptions made about such things as crop choice and 
cultivation practices, food production levels are estimated (Slingo et al. 2005; Lobell et al. 2008).

Scenario-based impact studies of this kind, sometimes called "top-down" or "endpoint" vulnerability assessments (O'Brien et al. 2004; Füssel and Klein 2006), are usually conducted at a global scale or at broad regional scales (Kunstmann and Jung 2005; Parry et al. 2005; Molua 2008; Läderach 2011; Sarr 2012). In order to isolate the effect of climate change, most other factors are assumed to be constant.

These impact studies provide important information on how long-term change in climatic norms is likely to affect yields and food production (Lobell et al. 2008; Thornton et al. 2011). In sub-Saharan Africa, such research has suggested that overall, East Africa will experience wetter weather and Southeast Africa will become drier (Kotir 2011). Changes in rainfall patterns are expected to result in loss of cropland (Niang et al. 2014; Kotir 2011). Crop yields in most of sub-Saharan Africa are estimated to fall by at least $10-20 \%$ by 2050 (Kotir 2011; Thornton et al. 2011). Arid and semiarid regions of the continent are expected to expand (Kotir 2011). In West Africa, it is expected that rainfall will be more variable and less predictable, which will reduce the length of the growing season. By 2050, West African yields could drop by 20-50\% (Sarr 2012).

Some scenario-based production impact studies also include hypothetical adaptation strategies in order to help understand how certain broad adaptations, such as the selection of crop varieties, might affect the estimated climate change impacts on food production (Parry et al. 2005; Crespo et al. 2011). In these analyses, theoretical adaptations are introduced in order to estimate the degree to which impacts might be moderated by widespread adjustments in crops or land use. For instance, assuming the amount of irrigated land in sub-Saharan Africa were doubled by 2050 (keeping total crop area constant), cereal production would increase by $5 \%$ (Calzadilla et al. 2010). Other research has shown that aggregated mean crop yields are expected to decrease by 6-24\% in sub-Saharan Africa, depending on the climate scenario and the type of crop management (e.g., single cropping vs. sequential cropping) used by farmers (Waha et al. 2013).

The main question addressed in climate scenario impact studies is "How much would food production change in an average year if temperature and precipitation norms differed from the current and everything else stayed the same, or if crop selection and land use were changed to match the predicted climate regime?" These studies provide limited insight into adaptation processes. They mostly deal with long-term temperature and precipitation norms and rarely address the interannual variability and extremes to which farmers are particularly sensitive (Smit and Pilifosova
2003; Berrang-Ford et al. 2011). The impact models do not investigate the practical feasibility of adaptations, the conditions that might facilitate or impede adoption of adaptive strategies, or the actual types of adaptations employed (Adger and Kelly 1999). Furthermore, this research conceptualizes climate change as the main driver for impacts on the human system. The approach does not substantially address how climate change interacts with other stressors, how these interactions affect people, and how people can and do behave.

Climate change impact studies of food production provide initial estimates into one aspect of food availability, but they are not designed to address the other aspects of food security, namely food access and food utilization. The implications for human well-being fall outside the scope of this work, and the consequences of climate change on human livelihoods are not explicitly analyzed.

The importance of situating climate change impacts as part of a multitude of stressors that can affect people, including their food security, has been recognized (Adger 2006; Smit and Wandel 2006; Tschakert 2007). This work draws on the fields of poverty, vulnerability, and livelihoods (e.g., Chambers 1995; Scoones 1998) in order to explicitly consider the experience of people in the analyses. This research attempts to understand and document the nature of the vulnerability of a human system (e.g., a household, a community, a society, a region, or a sector) to climatic and other stresses (e.g., socioeconomic, political, biophysical) by identifying the processes through which people experience and respond to climate change. These analyses, sometimes called "bottom-up" or "startingpoint" vulnerability approaches, tend to be local in scale, empirical, and use ethnographic and participatory research approaches (O'Brien et al. 2004; Füssel and Klein 2006).

Vulnerability research directly assesses adaptation by seeking to understand who or what adapts, to what stimuli, and how it occurs (Smit et al. 1999; Adger et al. 2003). The goal is to understand the adaptation process: how people have adapted to past changes, and what changes or conditions are relevant and can provide insight into how they will adapt in the future. Adjei-Nsiah et al. (2010) show that in Wenchi, Ghana, farmers consider poor rainfall distribution and frequent droughts as the most important climate-related changes. They are adapting to these changes by planting early-maturing and/or drought-resistant crops, planting early, and using agrochemicals. In South Africa and Ethiopia, farmers have noticed increases in temperature and a decrease in rainfall. Yet, a large proportion of the farmers in both countries did not undertake any adaptive measures (Bryan et al. 2009). Farmers named shortage of land (Ethiopia) and lack of access to credit (South Africa) as the main barriers to adaptation (Bryan et al. 2009). Other research documents the stressors to 
which people adapt. In northern Burkina Faso, farmers mentioned land scarcity and new market opportunities, rather than a changing climate, as the main reasons for changing their farming practices. They adapted by using micro-water harvesting techniques, storing hay and sorghum residues to feed livestock, and have adopted dry season vegetable production (Barbier et al. 2009).

Many regions in sub-Saharan Africa are heavily constrained by their limited social, political, and technical resources, which already affect their ability to cope with issues of scarcity and poverty. These constraints also hamper their ability to cope with changing environmental conditions (Downing et al. 1997; Westerhoff and Smit 2009). Community-based studies have provided insights into the various stresses that affect people and their livelihoods. In KwaZulu-Natal, South Africa, Reid and Vogel (2006) found that the multiple daily stresses in people's lives combined to increase their vulnerability to future climate change, and weak organizational support limited adaptation. Bunce et al. (2010) found that climate is an important livelihood stressor for people in Mozambique and Tanzania, and policy (and therefore institutions) is a key stressor that interacts with climate to increase people's vulnerability. In Senegal, climate change interacts with rural unemployment, poor health, and inadequate infrastructure to increase people's vulnerability (Tschakert 2007).

Climate change vulnerability studies have also been used to provide insight into how food security might be affected by climate change. In the Afram Plains region of Ghana, farmers are noticing delays in the onset of the rainy season, mid-season heat waves, and high-intensity rains that cause flooding, resulting in crop loss and low yields, and reducing the availability of household food (Codjoe and Owusu 2011). Flooding is also destroying local roads, leading to difficulty in transporting foodstuffs.

The work on climate change vulnerability and adaptation relates to food security and sustainable livelihoods through the recognition that climate change is one of numerous stressors acting upon people's livelihoods and that people's capacity to achieve food security is influenced by a variety of economic, institutional, and social conditions. In building their livelihoods and ensuring their food security, people respond to a variety of stresses, of which climate-related forces may not be the most pressing. The vulnerability work also indicates that food security involves more than food production alone.

\section{Food security}

Food security involves more than the amount of food available. The Food and Agriculture Organization (FAO) defines food security as "a situation that exists when all people, at all times, have physical, social and economic access to sufficient, safe and nutritious food that meets their dietary needs and food preferences for an active and healthy life" (World Food Summit 1996). While food security is commonly defined as a dichotomy (either it exists or it does not), it can vary by degree, over time, from household to household, or among communities. The conceptualization of food security reflects an evolution in the field. In the 1970s, food security was considered largely a function of food production, as evident in the World Food Conference in 1974 (Anderson and Cook 1999; Maxwell 1996; Baro and Deubel 2006). Sen (1981) is widely credited for introducing the concepts of entitlements and access to food security scholarship.

The common definition of food security rests on three pillars: food availability, food access, and food utilization (Webb et al. 2006; Ericksen et al. 2011). "Availability" refers to the production, distribution, and exchange of food and can be understood as the amount, type, and quality of food available for consumption. "Access" refers to the affordability, allocation, and preference of food and can be understood as the ability to access food of the required type, quality, and quantity. "Utilization" refers to the nutritional value, the social value, and the safety of food. It can be understood as the ability to consume and benefit from food. The availability of food is considered necessary, but not sufficient for its access, and its access is necessary, but is not sufficient for its utilization (Webb et al. 2006; Pinstrup-Andersen 2009; Barrett 2010). For example, food may be available in the market, but a person may lack the funds to purchase it (food is available, but the conditions for its access are not met); or the person may have the money to purchase the food, but it may not meet nutritional requirements, as it could be spoiled or unhealthy (food is accessible, but the conditions for utilization are not met).

\section{Food availability}

Food availability often remains the predominant aspect used in food security analysis and measurement. Indicators used to measure food availability include crop production and/or food production indices, livestock ownership indices, and national food balance sheets (Coates et al. 2006; Barrett 2010; Renzaho and Mellor 2010). For instance, the FAO derives its "undernourishment" estimates from national food balance sheets (which refer to a country's food supply) and assumptions of intra-national food distribution (de Haen et al. 2011). Productivity estimates are easy to procure at global, broad regional, and national levels, which may partly explain the persistence of the availability-based focus (Barrett 2010). 
Analyses that focus on availability and omit access and utilization can result in a skewed understanding of the extent of the food security situation (Misselhorn 2005).

\section{Access}

Access, or the ability to acquire food, is influenced by income level, access to resources, the physical and social environment, the cost of food, and government and trade policies (Renzaho and Mellor 2010). Food access has a strong institutional component, consistent with Sen's (1981) treatment of entitlements and his demonstration that entitlements failure leads to food insecurity. Access to food is often measured using proxy, entitlements-based indicators such as food consumption, food price monitoring, income, or assets (Webb et al. 2006; Baiphethi and Jacobs 2009; Renzaho and Mellor 2010).

In rural sub-Saharan Africa, the majority of the population practices subsistence agriculture, and supplements food stores with purchases from the market (Baiphethi and Jacobs 2009). There is often a "hungry season," which occurs when food stores are inadequate to carry a household to the next harvest, and people are particularly dependent upon market purchases (Thompson et al. 2010). Households therefore diversify their incomes by engaging in non-farm activities, such as wage employment (Barrett et al. 2001). Understanding household food security means situating it within the context of livelihoods.

\section{Utilization}

When food is available and accessible to a household, it does not mean that the household is food secure, unless the food is nutritious, safe, and socially acceptable by the members of the household (Webb et al. 2006; Renzaho and Mellor 2010). Determinants of food utilization include the ability to physically use the available food (e.g., having proper cooking utensils, culturally regulated feeding hierarchies, cuisine patterns, adequate housing) and the ability to biologically use the available food (e.g., absence of diarrheal or other diseases that impede biological food use, infection, etc.) (Renzaho and Mellor 2010; Vink 2012).

Food security and livelihoods

Food security is a multidimensional phenomenon that reflects a complex interaction of multiple stresses (e.g., political, institutional, social, biophysical, and economic) (Misselhorn 2005; Altman et al. 2009). Framing food security as an integral part or an outcome of a livelihood strategy recognizes that a host of stresses can interact to affect food security at a household or individual level.
Household-level scholarship on food security often draws on livelihood approaches. In fact, some define food security as the success of local livelihoods in guaranteeing access to sufficient food at the household level (Devereux and Maxwell 2001). The focus of household-level food security research is to study the strategies used by people to achieve food security, whether it be migration (Karamba et al. 2011), income diversification (Babatunde and Qaim 2010), or the use of technology (Burney and Naylor 2012), for example. Food security can be seen as one dimension of a broader livelihood strategy (Maxwell and Smith 1992).

In short, food security scholarship has progressed from an understanding of food security rooted in issues of world and regional food supply, to issues of household and individual food security that focus on access (Sen 1981), sustainability (Scoones 1998), and vulnerability to food insecurity (Chambers and Conway 1991; Watts and Bohle 1993).

\section{Sustainable livelihoods}

Chambers and Conway (1991, p. 6) define sustainable livelihoods as: "A livelihood comprises the capabilities, assets (stores, resources, claims and access) and activities required for a means of living: a livelihood is sustainable which can cope with and recover from stress and shocks, maintain or enhance its capabilities and assets, and provide sustainable livelihood opportunities for the next generation; and which contributes net benefits to other livelihoods at the local and global levels and in the short and long term."

The goal of livelihoods research is to analyze the diverse ways that people make a living (Kaag 2004; Scoones 2009). The field evolved from household and farming systems studies and draws upon the assets/processes/activities framework that was used in poverty reduction, sustainability, and livelihood strategies research (Scoones 1998; Ellis 1999; De Haan and Zoomers 2005). These approaches were driven by the need to deepen our understanding of poverty from a purely economic conceptualization (defined in terms of lack of income or GNP/capita), to the incorporation of basic needs (e.g., access to certain consumer goods and collective goods), to entitlements and the vulnerability of people to change (Carney et al. 1999; De Haan and Zoomers 2005).

Many sustainable livelihood approaches use an iteration of the "sustainable rural livelihoods" framework (Carney 2003). This framework emphasizes how people use a range of assets (natural, physical, social, human, and financial capitals)-sometimes conceptualized in the literature as "strengths" (Moser et al. 2001) — to devise livelihood strategies with the goal of achieving positive livelihood 
outcomes. In the framework, assets exist within a context of vulnerability, which is composed of the trends, shocks, and cultural practices that affect livelihoods. Structures (e.g., government, the private sector) and processes (e.g., laws, culture, institutions) influence people's access to assets (Moser et al. 2001; Carney 2003).

Sustainable livelihood approaches have been used to address a range of issues regarding development in subSaharan Africa, including:

- the effects of power and gender relations on the lives of specific groups of people (e.g., women) (Canagarajah et al. 2001; Mandel 2004; Oberhauser and Pratt 2004),

- the diversity of the strategies used by the rural poor to make a living (Abdulai and CroleRees 2001; Batterbury 2001; Smith et al. 2001; Manvell 2006; Yaro 2006),

- the success of climate change adaptation strategies (Assan et al. 2009; Jones et al. 2010; Osbahr et al. 2010),

- the effects of policies on the lives of the poor (Rakodi 1999; Barrett et al. 2001),

- issues of food security (Sutherland et al. 1999; Gladwin et al. 2001; Hesselberg and Yaro 2006; Codjoe and Owusu 2011), and

- the effects of global environmental change on the poor (Hahn et al. 2009).

In terms of food security, adopting a livelihood approach allows for a more thorough analysis of the forces that shape food insecurity at the household and individual level. Gladwin et al. (2001) investigated why African households, and especially women headed households, tend to be food insecure. They found that agriculture-based households could not rely on a single livelihood strategy, and cultural norms constrain women in their choice of livelihood strategies. Hesselberg and Yaro (2006) demonstrate that Ghanaian households require diverse livelihood strategies in order to reduce their food insecurity. They found that low food security is a result of poor biophysical conditions, low social capital and few opportunities for local non-farm income generating activities.

Sustainable livelihood approaches have shown themselves to be useful in capturing the processes and contextual factors that shape adaptive capacity (Scoones 1998; Carney 2003; Scoones 2009). A focus on the assets or capitals helps to establish what resources are available and accessible to aid in adaptation. For instance, Hahn et al. (2009) combined a sustainable livelihood approach with a climate change vulnerability assessment to create a livelihood vulnerability index that serves to determine the differential impacts of climate change on two communities in Mozambique, and to identify livelihood strategies, such as seed storage, that help in adapting to climate change.
The climate change, food security, and livelihoods framework

Notwithstanding the distinct foci of each of the bodies of research reviewed above, there are clearly considerable areas of overlap. In particular, any investigation into the implications of climate change for food security and livelihoods would benefit from drawing on aspects of all three, as each provides particular insights into the complexity of livelihoods, food security, and how people respond to the multiple stresses they experience.

Several frameworks have been developed that integrate elements from these fields. Wisner et al. (2004) outline frameworks that describe relationships among natural and social/political/economic processes that influence access to opportunities and exposure to hazards contributing to dynamic vulnerability. O'Brien and Leichenko (2000) propose a "double exposure" framework that guides research on the interactions of climate change impacts and globalization. Turner et al. (2003) develop a general model of coupled human-environment systems, with linkages, impacts, and adaptations across scales, reflected in vulnerability as a function of exposure, sensitivity, and resilience. Ford (2009) employs a vulnerability model, including exposure-sensitivity and adaptive capacity, to assess implications of climate for food security.

Ericksen (2008) develops frameworks to understand the interactions between global environmental change (GEC) and food systems and to evaluate some of the major outcomes of these interactions on food security (through its three pillars), ecosystem services, and social welfare. Major foci of the framework are the feedbacks and interactions among its GEC and socioeconomic drivers. These act upon the components of food systems, which include social, institutional, and ecological activities (e.g., producing, processing, distributing food), actors (e.g., farmers, distributors, consumers), and outcomes (e.g., food security, social welfare, environmental welfare). Livelihoods are addressed implicitly in that "food system outcomes" contribute to food security as well as social welfare and environmental or natural capital.

Among studies in Africa, Codjoe and Owusu (2011) draw on Rakodi's (2002) livelihoods approach to develop a food systems framework to assess the impacts of climate change on the three pillars of food security, and identify areas for adaptation. While multiple stressors are recognized, the predominant driver considered is climate change. The food systems approach was used to gain insight on how climate change is affecting a variety of aspects that determine the region's food security, such as food storage facilities, rural transportation, and cultural practices. This framework focuses specifically on the food security outcomes of livelihoods. 
Hesselberg and Yaro (2006) develop a livelihood vulnerability framework to assess the food insecurity situation in villages in marginal environments in northern Ghana. This framework conceptualizes vulnerability as the result of the interactions among the threats faced by people to their livelihoods (e.g., physical, economic, political shocks), their capabilities (a function of their sensitivity and their resilience), and the outcomes of their strategies. The framework does not deal specifically with the field of climate change, but recognizes that livelihoods are affected by a multitude of stressors (or threats).

Casale et al. (2010) present the Southern Africa Vulnerability Initiative (SAVI) framework, a conceptualization that explores the factors that influence vulnerability in Southern Africa. This model identifies multiple stressors that act on the contextual environment, which is composed of capitals (natural, physical, social, human, financial). Outcomes, particularly relevant to southern Africa, include food insecurity, conflict, HIV infection, and mortality. Special focus is brought to points of intervention, such as health care, food aid, or other home-based care.

The previously discussed frameworks explore different facets of the interactions among food security, livelihoods, and/or climate change IVA. This paper proposes a conceptual framework that is particularly suited to researching the implications of climate change in the context of multiple stressors on livelihoods and food security at the community level in sub-Saharan Africa. This conceptual framework (Fig. 1) serves to indicate the various aspects of a community that should be considered in an effort to characterize its vulnerability to changing conditions and its capacity to adapt, particularly as these relate to its food security. The framework serves, in part, as a "checklist" of relevant variables to consider in an analysis. It recognizes that there are several dimensions of food security and these are embedded and interconnected with other livelihood attributes and the natural resource base within which communities operate. The framework indicates key connections and interactions that represent important features of any assessment of the dynamic nature of a community's food security.

This conceptual framework provides an overall outline of the factors and interconnections that constrain and influence the nature and dynamics of a community's food security. "Community" as used here could be applied at any of several scales, such as a household or a village. Of course, within a community, there are likely to be significant differences in many of the conditions identified in the framework. For example, all people in a village will have a suite of assets and will be affected by biophysical (physical, biological, and ecological) and socioeconomic (social, economic, political and institutional) drivers, but the specific assets will likely vary among individuals and households, and their exposure to the drivers may also vary.
In this framework (Fig. 1), the vulnerability of a community is a function of the multiple and interrelated biophysical and socioeconomic drivers that act upon the community and shape its adaptive capacity. As in both the sustainable livelihoods field (Chambers 1989) and the climate change IVA field (Adger and Kelly 1999; Smit and Wandel 2006), vulnerability is seen to have two interconnected elements: one related to external risks, shocks, drivers, and stresses to which communities are subject, and one relating to the means of coping or capacity for adapting. Biophysical drivers include climate change and also other physical and biological conditions, such as disease, earthquakes, and soil quality. Socioeconomic drivers can include demographics, economics, institutions, and policies. Political conditions, institutional structures and processes, cultural norms, and market forces all represent important forces or drivers of vulnerability (Adger and Kelly 1999; Scoones 2009). The socioeconomic and biophysical drivers, or stressors, overlap to indicate that they interact to affect the community synergistically (Ericksen 2008). This conceptualization of drivers, also called stressors, hazards (Wisner et al. 2004), contextual conditions (Casale et al. 2010), or the livelihood environment (Scoones 1998) is broadly consistent with ideas in climate change IVA (O'Brien et al. 2009), sustainable livelihoods (Scoones 1998), and food security (Misselhorn 2005).

Adaptive capacity (Fig. 1) refers to the potential of a system to adjust itself to change (Watts and Bohle 1993; Smit et al. 2000; Turner et al. 2003; Füssel and Klein 2006). It is conceptually close to many interpretations of resilience (Nelson et al. 2007). Many climate change vulnerability scholars have drawn linkages between the capitals or entitlements (livelihood resources or assets) and adaptive capacity, particularly as it relates to social capital (Adger 2003; Pelling and High 2005). This framework conceptualizes adaptive capacity as the ability of a person or a community to use their assets or capitals in order to deal with or adapt to changing conditions.

Access to livelihood assets (natural, financial, social, physical, and human capitals) (Fig. 1) is shaped by characteristics of the community and by the multiple and interacting biophysical and socioeconomic drivers. The assets are the livelihood resources that people use in varying combinations to build their livelihood adaptation strategies (Scoones 1998). For example, in order to diversify its income, a household may choose to find employment on a neighbor's farm (hence using their natural, social, and human capitals). The ability of a household member to find employment may be determined by cultural norms (e.g., women may not be allowed to work outside of the household) and the current climatic conditions (which determine the season's successfulness, hence the neighbor's ability to hire outside help). Structural forces may 
Fig. 1 Climate change, food security, and livelihoods framework

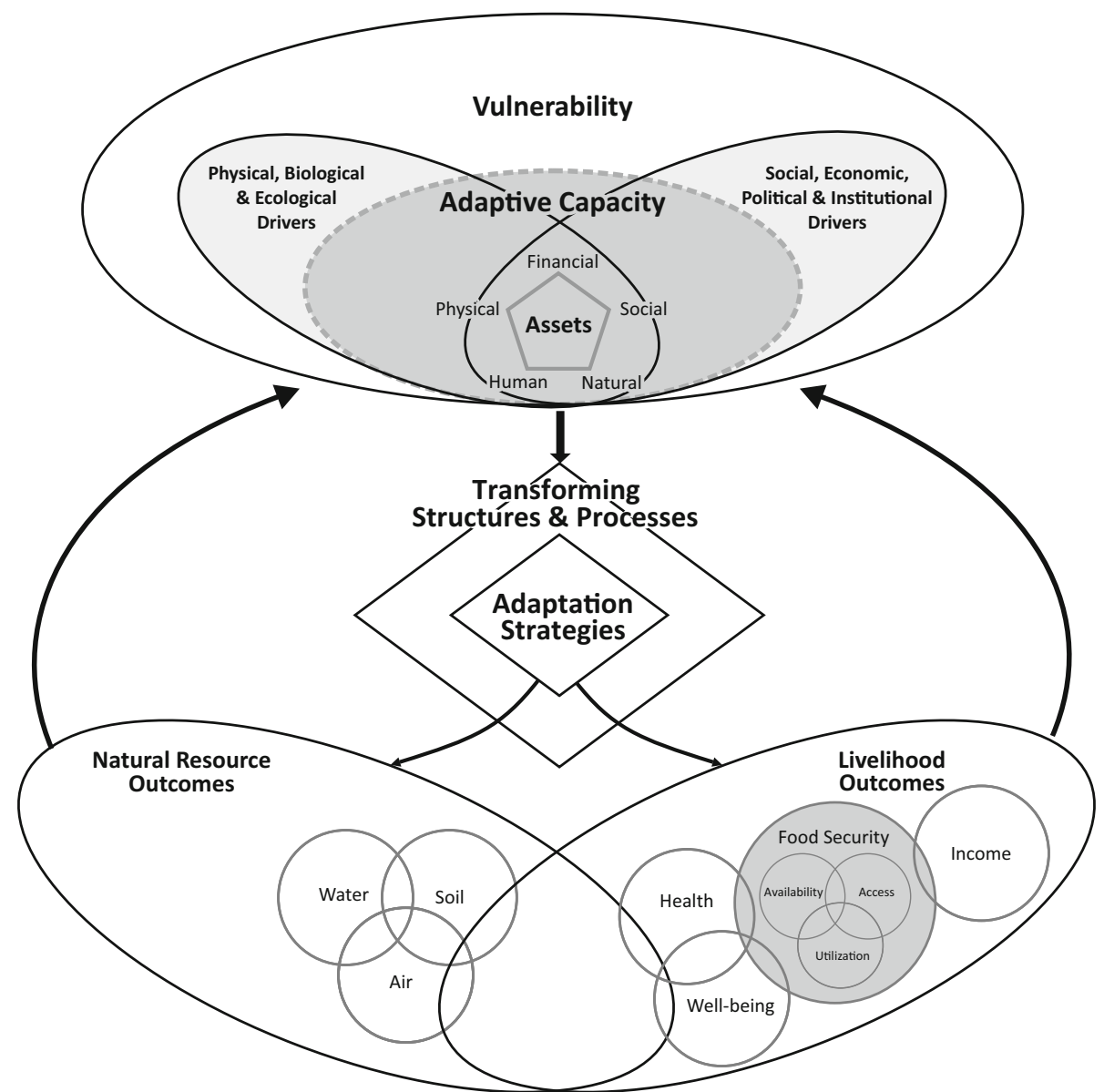

also affect access to assets. For instance, low commodity prices may be detrimental to profit for a cash crop. Governmental policies that determine where investments in infrastructure or services are made could also aid or constrain a community's ability to access markets, or its access to aid (including food aid).

Adjustments to stresses may occur via incremental adaptations and/or via transformations in institutional structures and processes. Adaptation strategies (Fig. 1) are the actions that people individually or collectively undertake to adjust to changing conditions in order to maintain or improve their well-being (e.g., agricultural intensification/ extensification, livelihood diversification, migration). They are the realization of adaptive capacity, as people draw upon their assets to adapt (Adger 2006; Smit and Wandel 2006). Transformational changes reflect higher-level adjustments in policies, programs, and institutions, or when thresholds are crossed in sociocultural or political economy systems (e.g., Nelson et al. 2007).

Transformations and adaptations are reflected in outcomes. Livelihood outcomes (Fig. 1) include changes in human well-being, income, health, and food security. Food security, through its three pillars, is a livelihood outcome, as it has been conceptualized in the field of sustainable livelihoods (Sutherland et al. 1999; Gladwin et al. 2001). Natural resource outcomes, also referred to as "ecosystem services" (Fisher et al. 2013), include (but are not limited to) changes in water, air or soil quality, and biodiversity.

In Fig. 1, the livelihood outcomes and natural resource outcomes overlap to indicate that they are not independent of each other. For example, an adaptation strategy that increases income, like the sale of livestock, may contribute to the depletion of soil fertility through the loss of manure but may contribute to biodiversity through reduction in overgrazing. Furthermore, the outcomes can change the system's vulnerability through feedbacks to its adaptive capacity (as illustrated by the arrows in the diagram). Livelihood outcomes that are positive in the short term (e.g., increased income), but deplete the natural resource base, may have negative feedback in the longer term by diminishing the physical assets available.

The framework shows how we can conceptualize and analyze the implications of climate change in a way that draws on common concepts in climate change IVA, sustainable livelihood approaches, and food security. The main application of this framework is to guide empirical 
research on the factors and interactions to consider when assessing ways in which climate change is likely to affect food security and livelihoods, in particular communities. It also provides policy makers and practitioners with a structured "checklist" to minimize the likelihood of ineffective initiatives. In the following section, the framework is used to structure a summary of findings from existing sub-Saharan African research.

\section{Insights from sub-Saharan Africa}

\section{Vulnerability}

Vulnerability results from the complex interactions of biophysical and socioeconomic drivers (or stressors) and the capitals that make up adaptive capacity. In sub-Saharan Africa, many countries are currently water stressed and climate change is projected to exacerbate the situation (Faramarzi et al. 2013). Additionally, some countries that are currently not water stressed are likely to experience stress in the future (Niang et al. 2014). With more than two-thirds of Africans dependent on rain-fed agriculture (World Bank 2009), communities are vulnerable to changes in water regimes, which are likely to be a major stressor on livelihoods. In many regions, erratic, unpredictable rainfall is an existing major stressor that is expected to worsen under climate change (Adjei-Nsiah et al. 2010; Codjoe and Owusu 2011; Tambo and Abdoulaye 2013). Farmers are already noticing changes in rainfall and in seasonality (Casale et al. 2010; Laube et al. 2012; Tambo and Abdoulaye 2013). They are experiencing unpredictability in the onset of the rainy season (Assan and Kumar 2009; Laube et al. 2012), increased incidences of drought (Hesselberg and Yaro 2006; Westerhoff and Smit 2009), and more intense rainfall, sometimes leading to increased flooding (Westerhoff and Smit 2009; Casale et al. 2010; Tschakert et al. 2010). These biophysical drivers act to deplete people's natural capital by shortening the growing season and decreasing soil moisture and soil fertility (Quaye 2008; Batisani 2012; Milgroom and Giller 2013). This can lead to seasonal crop failures and longterm production problems, resulting in food insecurity due to a reduction in the availability of food. Furthermore, low crop yields affect people's access to food, since households usually sell surplus at the market as a source of income. Hence, low crop yields are a stressor that acts on people's financial capital (Hesselberg and Yaro 2006; Yaro 2006; Codjoe and Owusu 2011).

Financial capital is also affected by high food costs. Globally, rising food costs further increase people's food insecurity, as they must spend a larger proportion of their income on eating, hindering their access to food (Batisani,
2012). A reduction in financial capital results in lower adaptive capacity, hence increased vulnerability. Other stressors that act on financial capital include the rising costs of goods, services, and labor (Hesselberg and Yaro 2006; Bunce et al. 2010), the removal of agricultural subsidies, and the lack of availability of loans (Hesselberg and Yaro 2006; Quaye 2008; Wilk et al. 2013).

Disease and other stresses on health contribute to vulnerability. Illness is sometimes related to a lack of reliable potable water (Westerhoff and Smit 2009). Disease reduces a household's human capital, as it often restricts people's ability to labor on the farm or undertake other household tasks. It also affects financial capital, as poor health and difficulty accessing health services limit households' ability to gain income (Hesselberg and Yaro 2006; Bunce et al. 2010; Casale et al. 2010; Wilk et al. 2013). In Ghana, rising healthcare costs due to economic liberalization policies can severely deplete a household's financial capital (Hesselberg and Yaro 2006).

Social capital plays an important role in people's adaptive capacity. In Mali, the gradual drying of lake Faguibine has meant that people living in the area, who used to depend on fishing, have had to adapt to a depleted form of natural capital by shifting to rearing livestock (Djoudi et al. 2013). These former fishers are short on experience and knowledge regarding livestock rearing, and government extension services have not adjusted themselves to their new needs. Therefore, a lack of social capital with respect to their new livelihood decreases their adaptive capacity and further increases their vulnerability.

In the Wenchi region of Ghana, farmers rely on their social capital to build their adaptation strategies (AdjeiNsiah et al. 2010). Farmers, and particularly migrant farmers whose financial and human capitals are low, partake in food and labor sharing in order to maintain their productivity.

Physical capital is also key to people's adaptive capacity. In Ghana's Afram Plains, communities that are better served by roads have more available food (Codjoe and Owusu 2011). When food production is not high enough to last until the next harvest, food continues to be available in the community at the market so long as roads remain operational.

\section{Adaptation strategies}

People use varied strategies to adjust to changes in their environment. In some situations, households undertake no adaptation to change (Bryan et al. 2009; Trærup and Mertz 2011; Tambo and Abdoulaye 2013). This can be due to a perception that the stressor is not critical (Patt and Schröter 2008), or to an inability to adapt (sometimes due to financial reasons) (Trærup and Mertz 2011). 
In reaction to changing rainfall patterns and in shorter growing seasons, some farmers are shifting to droughttolerant crops and fast-maturing varieties in order to adapt to shorter growing seasons (Trærup and Mertz 2011; Tambo and Abdoulaye 2013). These shifts are sometimes aided by social capital such as government programs and extension, or communication and support among farmers (Yaro 2006), demonstrating the important role of higherlevel structures and processes.

In South Africa, Thomas et al. (2007) show that a shortterm adaptation strategy to dry spells is to shift from cropping to livestock management. While this strategy is effective in reducing reliance on crops that may fail due to lack of rain, farmers are noting a reduction in grazing resources. One of the shift's outcomes is therefore having a negative impact on natural capital. Other changes in farming practices due to changes in rainfall include increasing planting distances in response to soil moisture deficits, introducing short-maturing varieties of maize in response to reduced rainfall at the end of the growing season, and the construction of stone bunds to curb soil erosion caused by more intense rainfall (Thomas et al. 2007). Farmers in this study also draw upon their social capital to build their adaptation strategies. They form cooperatives to reduce production and transportation costs. They also obtain help from government extension agencies to gain access to drought-resistant crop varieties and indigenous livestock breeds.

In Ghana, adaptive strategies in farming include intensification and extensification of crops, and experimentation with new crops, but only when support is available for inputs. Hence, farmers rely on social capital. Other coping strategies include applying inputs selectively to specific crop and land types, increasing the use of family labor (human capital), early harvesting of crops, and forming alliances with farmers to help in labor distribution (Yaro 2006).

Livelihood adaptation strategies in the face of rising costs are diverse. They range from borrowing from relatives, friends, or local banks, to withdrawing children from school and avoiding hospitals, to the diversification of activities to earn income. Deagrarianization, or livelihood diversification away from the farm, is a major adaptive strategy (Hesselberg and Yaro 2006; Yaro 2006; Tambo and Abdoulaye 2013). In Ghana, this strategy is most important in the dry season months and is also a key coping strategy when climate variability causes production failures (Yaro 2006).

Livelihood diversification allows households to access other sources of income when production is insufficient to feed the occupants (Hesselberg and Yaro 2006). Some adaptation strategies, such as selling livestock, may be helpful in the short term, providing money for food, schooling, medical, and other household needs. However, selling livestock can reduce manure input, depleting natural capital and resulting in lower food production (Hesselberg and Yaro 2006; Trærup and Mertz 2011).

Stressors can have differential impacts on community members, and adaptation strategies can vary by gender, social status, and so on. In Ghana, Codjoe et al. (2012) found differences in adaptation strategies between men and women. In response to flooding, women tended to prefer adopting post-harvest technology more than men, while men favoured light infrastructure projects such as the construction of community drains. Women's land rights tend to be restricted and are therefore less able to move their food production to less flood-prone areas. Post-harvest technologies therefore allow them to conserve a greater proportion of their flood-affected harvests.

\section{Outcomes}

Livelihood outcomes can also reflect both intended and unintended results of adaptation strategies. In East and West Africa, the construction of small reservoirs and rainwater storage facilities (built for domestic and irrigation purposes) has likely helped deal with rainfall variability but has also resulted in rising rates of water-related diseases, namely malaria and schistosomiasis (Boelee et al. 2013).

In northern Mali, the temporary out-migration of mostly male laborers has meant that women must undertake activities once reserved for men on top of their own activities. This increases their work burden, increases their vulnerability, and decreases their well-being (Djoudi et al. 2013).

In some regions, such as Wenchi, Ghana, changes in soil fertility and the length of the growing season have lead to people adapting by switching from cash crops (such as cocoa) to short-season and drought-tolerant crops such as maize, yam, and cowpea, which generate less income (Adjei-Nsiah et al. 2010).

\section{Conclusion}

The predominant approach to analyzing climate change and food security in sub-Saharan Africa has been to model the effects of future climate change scenarios on food production. While this provides valuable information on possible future yields and production levels under a changing climate, food security also involves issues of food accessibility and utilization. Food security is an integral part of people's well-being. Sustainable livelihood approaches have indicated that there are other important factors that influence people's livelihoods, such as income, health, and assets. 
The conceptual framework outlined here demonstrates the elements that the fields of climate change IVA, food security, and sustainable livelihoods contribute to an integrated model of the relationships among climate, food, and livelihoods. Many of the components and interrelationships outlined in the framework have been noted (and sometimes analyzed) elsewhere; this conceptualization synthesizes these with a focus on climate change and food security. Notably, the framework highlights climate change as but one stressor among many, and it is intricately interconnected with other biophysical and socioeconomic drivers. It recognizes that people's adaptive capacity reflects their access to assets, which in turn are shaped by the multiple drivers. People's potential and ability to undertake adaptation strategies are shaped by their access to natural, social, financial, physical, and human capitals. Adaptive strategies are the realization of adaptive capacity, and they take many forms and occur within transformations of sociopolitical and economic structures. Adaptation initiatives have consequences (sometimes unintended) for livelihood outcomes and natural resource outcomes. These consequences can feed back positively and/or negatively to the assets and to people's vulnerabilities.

Several of these features of the framework have already been recognized and acted upon elsewhere, particularly in the development community. For programs seeking to improve the livelihoods of people, reduce poverty, and enhance food security, it makes little sense to address climate change in isolation from the other powerful forces of change. Organizations such as the Food and Agriculture Organization, the World Bank, and the Research Program on Climate Change, Agriculture and Food Security (CCAFS) of the Consultative Group on International Agricultural Research (CGIAR) employ the "climate-smart agriculture" framework, which seeks to sustainably increase agricultural production while adapting to climate change and mitigating greenhouse gas emissions (FAO 2013; Neate 2013). Such developments are also evident in the most recent IPCC reports, although the clear focus remains on crop yields and production.

The framework is intended primarily to guide empirical studies especially at a community level. It is employed here to illustrate how findings from a variety of empirical case studies in sub-Saharan Africa fit within the framework. Improving our understanding of the relationships among climate, food, and livelihoods is more than a scholarly imperative-it is also necessary to help guide practical initiatives, such as policies, programs, and actions (including climate change adaptation), intended to sustain or improve the livelihoods and food security of people in sub-Saharan Africa as the climate continues to change.
Acknowledgments This research was funded by the Social Sciences and Humanities Research Council Doctoral Fellowship program, the Social Sciences and Humanities Research Council, and the Canada Research Chairs program. We wish to thank Evan Fraser and two anonymous reviewers for their helpful comments and Marie Puddister for producing the figure.

Open Access This article is distributed under the terms of the Creative Commons Attribution License which permits any use, distribution, and reproduction in any medium, provided the original author(s) and the source are credited.

\section{References}

Abdulai A, CroleRees A (2001) Determinants of income diversification amongst rural households in southern Mali. Food Policy 26(4):437-452. doi:10.1016/S0306-9192(01)00013-6

Adger WN (2003) Social capital, collective action, and adaptation to climate change. Econ Geogr 79(4):387-404. doi:10.2307/ 30032945

Adger WN (2006) Vulnerability. Glob Environ Chang 16(3):268-281. doi:10.1016/j.gloenvcha.2006.02.006

Adger WN, Kelly PM (1999) Social vulnerability to climate change and the architecture of entitlements. Mitig Adapt Strateg Glob Chang 4(3):253-266. doi:10.1023/A:1009601904210

Adger WN, Huq S, Brown K, Conway D, Hulme M (2003) Adaptation to climate change in the developing world. Prog Dev Stud 3(3):179-195. doi:10.1191/1464993403ps060oa

Adjei-Nsiah S, Issaka R, Fening J, Mapfumo P, Anchirina V, Giller K (2010) Farmers' perceptions of climate change and variability and existing opportunities for adaptation in Wenchi area of Ghana. Int J Clim Chang Impacts Responses 2(2):49-60

Akrofi S, Price LL, Struik PC (2012) HIV and severity of seasonal household food-related coping behaviors in rural Ghana. Ecol Food Nutr 51(2):148-175. doi:10.1080/03670244.2012.661347

Altman M, Hart TG, Jacobs PT (2009) Household food security status in South Africa. Agrekon 48(4):345-361. doi:10.1080/ 03031853.2009.9523831

Anderson MD, Cook JT (1999) Community food security: practice in need of theory? Agric Hum Values 16(2):141-150. doi:10.1023/ A: 1007580809588

Assan JK, Kumar P (2009) Introduction: livelihood options for the poor in the changing environment. J Int Dev 21(3):393-402. doi:10.1002/jid. 1565

Assan J, Caminade C, Obeng F (2009) Environmental variability and vulnerable livelihoods: minimising risks and optimising opportunities for poverty alleviation. J Int Dev 21(3):403-418. doi:10. 1002/jid.1563

Babatunde RO, Qaim M (2010) Impact of off-farm income on food security and nutrition in Nigeria. Food Policy 35(4):303-311. doi:10.1016/j.foodpol.2010.01.006

Baiphethi MN, Jacobs PT (2009) The contribution of subsistence farming to food security in South Africa. Agrekon 48(4):459-482. doi:10.1080/03031853.2009.9523836

Barbier B, Yacouba H, Karambiri H, Zoromé M, Somé B (2009) Human vulnerability to climate variability in the Sahel: farmers' adaptation strategies in northern Burkina Faso. Environ Manag 43(5):790-803. doi:10.1007/s00267-008-9237-9

Baro M, Deubel TF (2006) Persistent hunger: perspectives on vulnerability, famine, and food security in sub-Saharan Africa. Annu Rev Anthropol 35:521-538. doi:10.1146/annurev.anthro. 35.081705.123224

Barrett CB (2010) Measuring food insecurity. Science 327(5967):825-828. doi:10.1126/science. 1182768 
Barrett CB, Reardon T, Webb P (2001) Nonfarm income diversification and household livelihood strategies in rural Africa: concepts, dynamics, and policy implications. Food Policy 26(4):315-331. doi:10.1016/S0306-9192(01)00014-8

Bashir MK, Schilizzi S (2013) Determinants of rural household food security: a comparative analysis of African and Asian studies. J Sci Food Agric 93(6):1251-1258. doi:10.1002/jsfa.6038

Batisani N (2012) Climate variability, yield instability and global recession: the multi-stressor to food security in Botswana. Clim Dev 4(2):129-140. doi:10.1080/17565529.2012.728129

Batterbury S (2001) Landscapes of diversity: a local political ecology of livelihood diversification in south-western Niger. Cult Geog 8(4):437-464. doi:10.1177/096746080100800404

Berrang-Ford L, Ford JD, Paterson J (2011) Are we adapting to climate change? Glob Environ Chang 21(1):25-33. doi:10.1016/ j.gloenvcha.2010.09.012

Boelee E, Yohannes M, Poda JN, McCartney M, Cecchi P, Kibret S, Hagos F, Laamrani H (2013) Options for water storage and rainwater harvesting to improve health and resilience against climate change in Africa. Reg Environ Chang 13(3):509-519. doi:10.1007/s10113-012-0287-4

Brown ME, Hintermann B, Higgins N (2009) Markets, climate change, and food security in West Africa. Environ Sci Technol 43(21):8016-8020. doi:10.1021/es901162d

Bryan E, Deressa TT, Gbetibouo GA, Ringler C (2009) Adaptation to climate change in Ethiopia and South Africa: options and constraints. Environ Sci Policy 12(4):413-426. doi:10.1016/j. envsci.2008.11.002

Bunce M, Rosendo S, Brown K (2010) Perceptions of climate change, multiple stressors and livelihoods on marginal African coasts. Environ Dev Sustain 12(3):407-440. doi:10.1007/s10668-0099203-6

Burney JA, Naylor RL (2012) Smallholder irrigation as a poverty alleviation tool in sub-Saharan Africa. World Dev 40(1):110-123. doi:10.1016/j.worlddev.2011.05.007

Calzadilla A, Rehdanz K, Betts R, Falloon P, Wiltshire A, Tol RSJ (2010) Climate change impacts on global agriculture. Kiel working paper, no. 1617

Canagarajah S, Newman C, Bhattamishra R (2001) Non-farm income, gender, and inequality: evidence from rural Ghana and Uganda. Food Policy 26(4):405-420. doi:10.1016/S0306-9192(01)00011-2

Carney D (2003) Sustainable livelihoods approaches: progress and possibilities for change. Department for International Development, London

Carney D, Drinkwater M, Rusinow T, Neefjes K, Wanmali S, Singh N (1999) Livelihoods approaches compared: a brief comparison of the livelihoods approaches of the UK department for international development (DFID), CARE, Oxfam and the United Nations Development Programme (UNDP). Department for International Development, London

Casale M, Drimie S, Quinlan T, Ziervogel G (2010) Understanding vulnerability in Southern Africa: comparative findings using a multiple-stressor approach in South Africa and Malawi. Reg Env Chang 10(2):157-168. doi:10.1007/s10113-009-0103-y

Challinor A, Wheeler T, Garforth C, Craufurd P, Kassam A (2007) Assessing the vulnerability of food crop systems in Africa to climate change. Clim Chang 83(3):381-399. doi:10.1007/ s10584-007-9249-0

Chambers R (1989) Editorial introduction: vulnerability, coping and policy. IDS Bull 20(2):1-7. doi:10.1111/j.1759-5436.1989. mp20002001.x

Chambers R (1995) Poverty and livelihoods: whose reality counts? Environ Urban 7(1):173-204. doi:10.1177/095624789500700106

Chambers R, Conway GR (1991) Sustainable rural livelihoods: practical concepts for the 21 st century. Institute of Development Studies. IDS discussion paper 296
Chen H, Githeko AK, Zhou G, Githure JI, Yan G (2006) New records of Anopheles arabiensis breeding on the Mount Kenya highlands indicate indigenous malaria transmission. Malar J 5:17. doi:10. $1186 / 1475-2875-5-17$

Coates J, Frongillo EA, Rogers BL, Webb P, Wilde PE, Houser R (2006) Commonalities in the experience of household food insecurity across cultures: what are measures missing? J Nutr 136(5): $1438 \mathrm{~S}-1448 \mathrm{~S}$

Codjoe SNA, Owusu G (2011) Climate change/variability and food systems: evidence from the Afram Plains, Ghana. Reg Env Change 11(4):753-765. doi:10.1007/s10113-011-0211-3

Codjoe SNA, Atidoh LK, Burkett V (2012) Gender and occupational perspectives on adaptation to climate extremes in the Afram plains of Ghana. Clim Chang 110(1-2):431-454. doi:10.1007/ s10584-011-0237-z

Crespo O, Hachigonta S, Tadross M (2011) Sensitivity of southern African maize yields to the definition of sowing dekad in a changing climate. Clim Chang 106(2):267-283. doi:10.1007/ s10584-010-9924-4

Davidson O, Halsnęs K, Huq S, Kok M, Metz B, Sokona Y, Verhagen J (2003) The development and climate nexus: the case of subSaharan Africa. Clim Policy 3:S97-S113. doi:10.1016/j.clipol. 2003.10.007

De Haan L, Zoomers A (2005) Exploring the frontier of livelihoods research. Dev Chang 36(1):27-47. doi:10.1111/j.0012-155X. 2005.00401.x

de Haen H, Klasen S, Qaim M (2011) What do we really know? Metrics for food insecurity and undernutrition. Food Policy 36(6):760-769. doi:10.1016/j.foodpol.2011.08.003

Devereux S (2007) The impact of droughts and floods on food security and policy options to alleviate negative effects. Agric Econ 37:47-58. doi:10.1111/j.1574-0862.2007.00234.x

Devereux S, Maxwell S (2001) Food security in sub-Saharan Africa. Intermediate Technology Development Group Publishing, London

Djoudi H, Brockhaus M, Locatelli B (2013) Once there was a lake: vulnerability to environmental changes in northern Mali. Reg Env Chang 13(3):493-508. doi:10.1007/s10113-011-0262-5

Downing TE, Ringius L, Hulme M, Waughray D (1997) Adapting to climate change in Africa. Mitig Adapt Strateg Glob Chang 2(1):19-44. doi:10.1007/BF02437055

Ellis F (1999) Rural livelihood diversity in developing countries: evidence and policy implications. Natural resource perspectives, 40. EMBRAPA-CPAF Amapa

Ericksen PJ (2008) Conceptualizing food systems for global environmental change research. Glob Environ Chang 18(1):234-245. doi:10.1016/j.gloenvcha.2007.09.00

Ericksen P, Thornton P, Notenbaert A, Cramer L, Jones P, Herrero M (2011) Mapping hotspots of climate change and food insecurity in the global tropics. CCAFS report, 5

FAO (2013) Climate-smart agriculture sourcebook. Food and Agriculture Organization, Rome

Faramarzi M, Abbaspour KC, Ashraf Vaghefi S, Farzaneh MR, Zehnder AJ, Srinivasan R, Yang H (2013) Modeling impacts of climate change on freshwater availability in Africa. J Hydrol 480:85-101. doi:10.1016/j.jhydrol.2012.12.016

Fauchereau N, Trzaska S, Richard Y, Roucou P, Camberlin P (2003) Sea-surface temperature co-variability in the Southern Atlantic and Indian oceans and its connections with the atmospheric circulation in the southern hemisphere. Int $\mathrm{J}$ Climatol 23(6):663-677. doi:10.1002/joc.905

Fisher JA, Patenaude G, Meir P, Nightingale AJ, Rounsevell MD, Williams M, Woodhouse IH (2013) Strengthening conceptual foundations: analysing frameworks for ecosystem services and poverty alleviation research. Glob Environ Chang 23(5):1098-1111. doi:10.1016/j.gloenvcha.2013.04.002 
Ford J (2009) Vulnerability of Inuit food systems to food insecurity as a consequence of climate change: a case study from Igloolik, Nunavut. Reg Environ Chang 9:83-100. doi:10.1007/s10113008-0060-X

Funk C, Dettinger MD, Michaelsen JC, Verdin JP, Brown ME, Barlow M, Hoell A (2008) Warming of the Indian Ocean threatens eastern and southern African food security but could be mitigated by agricultural development. Proc Natl Acad Sci USA 105(32):11081-11086. doi:10.1073/pnas.0708196105

Füssel HM, Klein RJT (2006) Climate change vulnerability assessments: an evolution of conceptual thinking. Clim Chang 75:301-329. doi:10.1007/s10584-006-0329-3

Gladwin CH, Thomson AM, Peterson JS, Anderson AS (2001) Addressing food security in Africa via multiple livelihood strategies of women farmers. Food Policy 26(2):177-207. doi:10.1016/S0306-9192(00)00045-2

Hahn MB, Riederer AM, Foster SO (2009) The livelihood vulnerability index: a pragmatic approach to assessing risks from climate variability and change - a case study in Mozambique. Glob Environ Chang 19(1):74-88. doi:10.1016/j.gloenvcha. 2008.11.002

Hay SI, Cox J et al (2002) Climate change and the resurgence of malaria in the East African Highlands. Nature 415(6874):905-909. doi:10.1038/415905a

Hesselberg J, Yaro JA (2006) An assessment of the extent and causes of food insecurity in northern Ghana using a livelihood vulnerability framework. GeoJournal 67(1):41-55. doi:10.1007/ s10708-006-9007-2

IPCC (2007) Summary for policymakers. In: Parry ML, Canziani OF, Palutikof JP, van der Linden PJ, Hanson CE (eds) Climate change 2007: impacts, adaptation and vulnerability. Contribution of working group II to the fourth assessment report of the intergovernmental panel on climate change. Cambridge University Press, Cambridge, pp 7-22

Jones L, Jaspars S, Pavanello S, Ludi E, Slater R, Arnall A, Grist N, Mtisi S (2010) Responding to a changing climate: exploring how disaster risk reduction, social protection and livelihoods approaches promote features of adaptive capacity. Working paper 319. Overseas Development Institute, London

Kaag M (2004) Ways forward in livelihood research. In: Kalb D, Pansters W, Siebers H (eds) Globalization and development. Springer, Netherlands, pp 49-74

Karamba WR, Quiñones EJ, Winters P (2011) Migration and food consumption patterns in Ghana. Food Policy 36(1):41-53. doi:10.1016/j.foodpol.2010.11.003

Kebede A, Hasen A, Negatu W (2011) A comparative analysis of vulnerability of pastoralists and agro-pastoralists to climate change: a case study in Yabello Woreda of Oromia Region, Ethiopia. Ethiop J Dev Res 33(1):61-95. doi:10.4314/ejdr.v32i2. 68611

Kotir JH (2011) Climate change and variability in sub-Saharan Africa: a review of current and future trends and impacts on agriculture and food security. Environ Dev Sustain 13(3):587-605. doi:10.1007/s10668-010-9278-0

Kunstmann H, Jung G (2005) Impact of regional climate change on water availability in the Volta basin of West Africa. In: Regional hydrological impacts of climatic variability and change. Proceedings of symposium S6 held during the seventh international association of hydrological sciences scientific assembly at Foz do Iguaçu, April 2005, vol 295. IAHS Publication, Brazil, pp 75-85

Läderach P (2011) Predicting the impact of climate change on the cocoa-growing regions in Ghana and Côte d'Ivoire (final report). Climate change agriculture and food security

Laube W, Schraven B, Awo M (2012) Smallholder adaptation to climate change: dynamics and limits in northern Ghana. Clim Chang 111(3-4):753-774. doi:10.1007/s10584-011-0199-1
Levine S, Chastre C, Ntububa S, MacAskill J, LeJeune S, Guluma Y, Acidri J, Kirkwood A (2004) Missing the Point: An analysis of food security interventions in the Great Lakes. Overseas Development Institute, London

Lobell DB, Burke MB, Tebaldi C, Mastrandrea MD, Falcon WP, Naylor RL (2008) Prioritizing climate change adaptation needs for food security in 2030. Science 319(5863):607-610. doi:10. $1126 /$ science. 1152339

Mandel J (2004) Mobility matters: women's livelihood strategies in Porto Novo, Bénin. Gend Place Cult A J Fem Geogr 11(2):257-287. doi:10.1080/0966369042000218482

Manvell A (2006) Sahelian action spaces: an examination of livelihood configurations in a rural Hausa community. J Int Dev 18(6):803-818. doi:10.1002/jid.1315

Maxwell DG (1996) Food security: a post-modern perspective. Food Policy 21(2):155-170. doi:10.1016/0306-9192(95)00074-7

Maxwell S, Smith M (1992) Household food security: a conceptual review. In: Household food security: Concepts, indicators, measurements: a technical review. United Nations Children's FundInternational Fund for Agricultural Development, New York

Milgroom J, Giller E (2013) Courting the rain: rethinking seasonality and adaptation to recurrent drought in semi-arid southern Africa. Agric Syst 118:91-104. doi:10.1016/j.agsy.2013.03.002

Misselhorn A (2005) What drives food insecurity in southern Africa? A meta-analysis of household economy studies. Glob Environ Chang 15:33-43. doi:10.1016/j.gloenvcha.2004.11.003

Molua EL (2008) Turning up the heat on African agriculture: the impact of climate change on Cameroon's agriculture. AfJARE 2(1):45-64

Moser CO, Norton A, Conway T, Ferguson C, Vizard P (2001) To claim our rights: livelihood security, human rights and sustainable development. Overseas Development Institute, London

Müller C, Cramer W, Hare WL, Lotze-Campen H (2011) Climate change risks for African agriculture. Proc Natl Acad Sci USA 108(11):4313-4315. doi:10.1073/pnas.1015078108

Neate P (2013) Climate-smart agriculture: success stories from farming communities around the world. Climate Change Agriculture and Food Security, The Netherlands

Nelson DR, Adger WN, Brown K (2007) Adaptation to environmental change: contributions of a resilience framework. Ann Rev Environ Resour 32(1):395-419. doi:10.1146/annurev.energy.32. 051807.090348

New M, Hewitson B, Stephenson DB, Tsiga A, Kruger A, Manhique A, Gomez B, Coelho CAS, Masisi DN, Kululanga E (2006) Evidence of trends in daily climate extremes over southern and West Africa. J Geophys Res 111(7):D14102. doi:10.1029/ 2005JD006289

Niang I, Ruppel OC, Abdrabo MA, Essel A, Lennard C, Padgham J, Urquhart P (2014) Africa. In: Barros VR, Field CB, Dokken DJ, Mastrandrea MD, Mach KJ, Bilir TE, Chatterjee M, Ebi KL, Estrada YO, Genova RC, Girma B, Kissel ES, Levy AN, MacCracken S, Mastrandrea PR, White LL (eds) Climate change 2014: impacts, adaptation, and vulnerability. Part B: regional aspects. Contribution of working group II to the fifth assessment report of the intergovernmental panel on climate change. Cambridge University Press, Cambridge, pp 1199-1265

O'Brien K, Quinlan T, Ziervogel G (2009) Vulnerability interventions in the context of multiple stressors: lessons from the southern Africa vulnerability initiative (SAVI). Environ Sci Policy 12(1):23-32. doi:10.1016/j.envsci.2008.10.008

Oberhauser A, Pratt A (2004) Women's collective economic strategies and political transformation in rural South Africa. Gend Place Cult A J Fem Geogr 11(2):209-228. doi:10.1080/ 0966369042000218464

O'Brien KL, Leichenko RM (2000) Double exposure: assessing the impacts of climate change within the context of economic 
globalization. Glob Environ Chang 10(3):221-232. doi:10.1016/ S0959-3780(00)00021-2

O'Brien K, Eriksen S, Schjolden A, Nygaard L (2004) What's in a word? Conflicting interpretations of vulnerability in climate change research. CICERO working paper 2004:04. Center for International Climate and Environmental Research, Oslo

Osbahr H, Twyman C, Adger WN, Thomas DSG (2010) Evaluating successful livelihood adaptation to climate variability and change in southern Africa. Ecol Soc 15(2): 27

Parry M, Rosenzweig C, Livermore M (2005) Climate change, global food supply and risk of hunger. Philos Trans R Soc B 360(1463):2125-2138. doi:10.1098/rstb.2005.1751

Patt A, Schröter D (2008) Perceptions of climate risk in Mozambique: implications for the success of adaptation strategies. Glob Environ Chang 18(3):458-467. doi:10.1016/j.gloenvcha.2008. 04.002

Pelling M, High C (2005) Understanding adaptation: what can social capital offer assessments of adaptive capacity? Glob Environ Chang 15:308-319. doi:10.1016/j.gloenvcha.2005.02.001

Perch L (2011) Mitigation of what and by what? Adaptation by whom and for whom? Dilemmas in delivering for the poor and the vulnerable in international climate policy. Working paper 79. International Policy Centre for Inclusive Growth (IPC-IG). UNDP, Brasilia

Pinstrup-Andersen P (2009) Food security: definition and measurement. Food Secur 1(1):5-7. doi:10.1007/s12571-008-0002-y

Porter JR, Xie L, Challinor AJ, Cochrane K, Howden SM, Iqbal MM, Lobell DB, Travasso MI (2014) Food security and food production systems. In: Field CB, Barros VR, Dokken DJ, Mach KJ, Mastrandrea MD, Bilir TE, Chatterjee M, Ebi KL, Estrada YO, Genova RC, Girma B, Kissel ES, Levy AN, MacCracken S, Mastrandrea PR, White LL (eds) Climate change 2014: impacts, adaptation, and vulnerability. Part A: global and sectoral aspects. Contribution of working group II to the fifth assessment report of the intergovernmental panel on climate change. Cambridge University Press, Cambridge, pp 485-533

Quaye W (2008) Food security situation in northern Ghana, coping strategies and related constraints. Afr J Agric Res 3(5):334-342

Rakodi C (1999) A capital assets framework for analysing household livelihood strategies: implications for policy. Dev Policy Rev 17(3):315-342. doi:10.1111/1467-7679.00090

Rakodi C (2002) A livelihoods approach: conceptual issues and definitions. In: Rakodi C, Lloyd JT (eds) A people-centred approach to reducing poverty. Earthscan, London, pp 3-22

Reich PF, Numben ST, Almaraz R, Eswaran H (2001) Land resources stresses and desertification in Africa. Agro-Science 2(2):1-10. doi:10.4314/as.v2i2.1484

Reid P, Vogel C (2006) Living and responding to multiple stressors in South Africa-glimpses from Kwazulu-Natal. Glob Environ Chang 16(2):195-206. doi:10.1016/j.gloenvcha.2006.01.003

Renzaho AM, Mellor D (2010) Food security measurement in cultural pluralism: missing the point or conceptual misunderstanding? Nutrition 26(1):1-9. doi:10.1016/j.nut.2009.05.001

Richard Y, Fauchereau N, Poccard I, Rouault M, Trzaska S (2001) 20th century droughts in southern Africa: spatial and temporal variability, teleconnections with oceanic and atmospheric conditions. Int J Climatol 21(7):873-885. doi:10.1002/joc.656

Sarr B (2012) Present and future climate change in the semi-arid region of West Africa: a crucial input for practical adaptation in agriculture. Atmos Sci Lett 13(2):108-112. doi:10.1002/asl.368

Scoones I (1998) Sustainable rural livelihoods: a framework for analysis, vol 72. Institute of Development Studies, Brighton

Scoones I (2009) Livelihoods perspectives and rural development. J Peasant Stud 36(1):171-196. doi:10.1080/03066150902820503

Sen A (1981) Ingredients of famine analysis: availability and entitlements. Q J Econ 96(3):433-464. doi:10.2307/1882681
Slingo JM, Challinor AJ, Hoskins BJ, Wheeler TR (2005) Introduction: food crops in a changing climate. PhilOS Trans R Soc B 360(1463):1983-1989. doi:10.1098/rstb.2005.1755

Smit B, Pilifosova O (2003) From adaptation to adaptive capacity and vulnerability reduction. In: Smith J, Klein RTJ, Huq S (eds) Climate change, adaptive capacity and development. Imperial College Press, London, pp 9-28

Smit B, Wandel J (2006) Adaptation, adaptive capacity and vulnerability. Glob Environ Chang 16:282-292. doi:10.1016/j. gloenvcha.2006.03.008

Smit B, Burton I, Klein R, Street R (1999) The science of adaptation: a framework for assessment. Mitig Adapt Strateg Glob Chang 4:199-213. doi:10.1023/A:1009652531101

Smit B, Burton I, Klein RJT, Wandel J (2000) An anatomy of adaptation to climate change and variability. Clim Chang 45:223-251. doi:10.1023/A:1005661622966

Smith DR, Gordon A, Meadows K, Zwick K (2001) Livelihood diversification in Uganda: patterns and determinants of change across two rural districts. Food Policy 26(4):421-435. doi:10. 1016/S0306-9192(01)00012-4

Songok CK, Kipkorir EC, Mugalavai EM (2011a) Integration of indigenous knowledge systems into climate change adaptation and enhancing food security in Nandi and Keiyo districts, Kenya. In: Filho WL (ed) Experiences of climate change adaptation in Africa. Springer, Hamburg, pp 69-95

Songok CK, Kipkorir EC, Mugalavai EM, Kwonyike AC, Ngweno C (2011b) Improving the participation of agro-pastoralists in climate change adaptation and disaster risk reduction policy formulation: a case study from Keiyo district, Kenya. In: Filho WL (ed) Experiences of climate change adaptation in Africa. Springer, Hamburg, pp 55-68

Sutherland AJ, Irungu JW, Kang'ara J, Muthamia J, Ouma J (1999) Household food security in semi-arid Africa-the contribution of participatory adaptive research and development to rural livelihoods in eastern Kenya. Food Policy 24(4):363-390. doi:10. 1016/S0306-9192(99)00050-0

Swift J (1989) Why are rural people vulnerable to famine? IDS Bull 20(2):41-49. doi:10.1111/j.1759-5436.2006.tb00285.x

Tambo JA, Abdoulaye T (2013) Smallholder farmers' perceptions of and adaptations to climate change in the Nigerian savanna. Reg Env Chang 13(2):375-388. doi:10.1007/s10113-012-0351-0

Thomas DSG, Twyman C, Osbahr H, Hewitson B (2007) Adaptation to climate change and variability: farmer responses to intraseasonal precipitation trends in South Africa. Clim Chang 83(3):301-322. doi:10.1007/s10584-006-9205-4

Thompson J, Scoones I (2009) Addressing the dynamics of agri-food systems: an emerging agenda for social science research. Environ Sci Policy 12(4):386-397. doi:10.1016/j.envsci.2009. 03.001

Thompson HE, Berrang-Ford L, Ford JD (2010) Climate change and food security in sub-Saharan Africa: a systematic literature review. Sustain 2(8):2719-2733. doi:10.3390/su2082719

Thornton PK, Jones PG, Ericksen PJ, Challinor AJ (2011) Agriculture and food systems in sub-Saharan Africa in a $4 \mathrm{C}+$ world. Philos Trans R Soc A 369(1934):117-136. doi:10.1098/rsta.2010.0246

Trærup SLM, Mertz O (2011) Rainfall variability and household coping strategies in northern Tanzania: a motivation for districtlevel strategies. Reg Environ Chang 11(3):471-481. doi:10. 1007/s10113-010-0156-y

Tschakert P (2007) Views from the vulnerable: understanding climatic and other stressors in the Sahel. Glob Environ Chang 17(3-4):381-396. doi:10.1016/j.gloenvcha.2006.11.008

Tschakert P, Sagoe R, Ofori-Darko G, Codjoe SN (2010) Floods in the Sahel: an analysis of anomalies, memory, and anticipatory learning. Clim Chang 103:1-32. doi:10.1007/s10584-0099776-y 
Turner BL, Kasperson RE, Matson PA, McCarthy JJ, Corell RW, Christensen L, Eckley N, Kasperson JX, Luers A, Martello ML, Polsky C, Pulsipher A, Schiller A (2003) A framework for vulnerability analysis in sustainability science. Proc Natl Acad Sci USA 100(14):8074-8079. doi:10.1073/pnas.1231335100

Vink N (2012) Food security and African agriculture. S Afr J Int Aff 19(2):157-177. doi:10.1080/10220461.2012.706489

Waha K, Müller C, Bondeau A, Dietrich P, Kurukulasuriya P, Heinke J, Lotze-Campen H (2013) Adaptation to climate change through the choice of cropping system and sowing date in sub-Saharan Africa. Glob Environ Chang 23(1):130-143. doi:10.1016/j. gloenvcha.2012.11.001

Watts MJ, Bohle HG (1993) Hunger, famine and the space of vulnerability. GeoJournal 30(2):117-125. doi:10.1007/ BF00808128

Webb P, Coates J, Frongillo EA, Rogers BL, Swindale A, Bilinsky P (2006) Measuring household food insecurity: why it's so important and yet so difficult to do. J Nutr 136(5):1404S

Westerhoff L, Smit B (2009) The rains are disappointing us: dynamic vulnerability and adaptation to multiple stressors in the Afram
Plains, Ghana. Mitig Adapt Strateg Glob Chang 14:317-337. doi:10.1007/s11027-008-9166-1

Wilk J, Andersson L, Warburton M (2013) Adaptation to climate change and other stressors among commercial and small-scale South African farmers. Reg Environ Chang 13(2):273-286. doi:10.1007/s10113-012-0323-4

Wisner B, Blaikie P, Cannon T, Davis I (2004) At risk: natural hazards, people's vulnerability, and disasters. Routledge, New York

World Bank (2009) Making development climate resilient: a world bank strategy for sub-Saharan Africa. World Bank, Washington, DC

World Food Summit (1996) Rome declaration on world food security and world food summit plan of action. http://www.fao.org/ DOCREP/003/W3613E/W3613E00.HTM. Accessed 21 Sept 2014

Yaro JA (2006) Is deagrarianisation real? A study of livelihood activities in rural northern Ghana. J Mod Afr Stud 44(01):125-156. doi:10.1017/S0022278X05001448 